\title{
THE SPEECH ACT OF APOLOGY IN SETSWANA EDUCATIONAL CONTEXTS
}

\author{
Bridget Mangwegape \\ Dr., Central University of Technology, SOUTH AFRICA, bmangwegape@cut.ac.za
}

\begin{abstract}
The main purpose of this paper encompasses the analysis of certain aspects of the speech act of apology in Setswana. Those aspects include the selection of the strategy used in the expression of apologizing and the participation of gender. The model of Brown and Levinson provides social factors which affects the way a speaker apologizes for an offence.

The data for this study was collected by means of quantitative analysis, which was administered among 22 B.Ed. second year Setswana students. The participants were provided with the questionnaire that consists of a social situation and in each situation the respondent has committed an offence to someone and has to apologize to the person. The offence affected persons belong to different social backgrounds and have different relations with the respondents from formal to informal situations. The researcher analyses the effects that different aspects have on the apology strategies which males and females use in different contexts. The findings in terms of apology situations and apology strategies displayed certain similarities and differences as a result.
\end{abstract}

Keywords: Apology situations, Apology strategies, Gender, Education.

\section{INTRODUCTION}

Apologies are generally aimed at face redress associated with face threatening acts (FTAs) or offences which have dented the recipient's face in some respect and can be regarded as negative politeness strategies (Brown \& Levinson (1978). However, the speech act serves most directly as the apology functions as a negative politeness strategy, accompanying elements may address transgressions to positive or negative face wants. To address the victim's face loss, apologies may instantaneously address the loss of positive face incurred by the speaker, as the remedial exchange includes the explanation where the speaker's positive face needs are usually considered. The model redresses the situation.

( $A$ is phoning $B$ to warn her of potential inconvenience)

A: I am sorry, but I am going to be a bit late for work. The busses are not off strike yet and with it being a wet Friday, it would probably be a while until my taxi arrives.

B: Uh-huh as long as you are here by six, because I am going then.

Though FTAs are normally described and analysed as unintentional transgression or at least as transgressions that cannot easily be avoided, as apologies may be in some circumstances be associated with deliberate offences. Austin (1988) introduced the term face attack act (FAA) for that subcategory of 
FTAs that involve intentional attacks on the recipient's face such as insults and accusations. An apology associated with FAA will often be performed by someone other than the face attacker, who nevertheless takes responsibility for the offense caused.

( $A$ is a child, $C$, has insulted her playmate, $B$, who is a guest at A's house)

C: Go away you are mean, and I hate you.

A: Sally! It is all right Bridget; she does not mean it. She is just a bit scratchy today.

B: (No visible response. Carries on playing)

It is also possible, however, for the face attacker herself to apologize for the FAA. This involves very explicitly what Goffman described as "a splitting of the self into a blameworthy part and a part that stands back and sympathizes with the blame-giving" Goffman 1971, p.113), that is, a simultaneous recognition of the offence and an attempt to dissociate oneself from the offending action:

(A, reneging on an earlier agreement, tells B's family that she cannot now put them up. B can reasonably feel insulted and discounted. Apology comes sometime later.)

A: Look I am terribly sorry for what happened. I was in an impossible position. I just could not please everyone.

B: That is Ok. I understand, though I must admit I felt pretty hurt at that time.

Like many utterances, those serving as apologies can express other functions too. Utterances which express regret for any offense may also serve as an admission, with the recipient learning of the offense through the utterance which serves as an apology. Thus, one utterance simultaneously performs the function of conveying bad news. (Brown \& Levinson, 1978) and apologizing for it.

(In trying to open a bottle for B, A breaks the cap.)

A: Oh dear, I am afraid I have broken it!

B: Never mind at least it is open now!

Such utterances like these illustrate the complexity of interaction since they simultaneously express the FTA while administering face redress as a politeness strategy mitigating the effect of the FTA. An utterance which serves as an apology simultaneously provides an explanation or excuse for the offense. The categorization as apology often depends on appropriate "apologetic" intonation in these situations.

(A has started to eat before B, the family's guest, has served herself to all the food available.)

A: I am so hungry; I cannot wait any longer.

B: Do not worry, go ahead.

At more general level, Norrick (1978, p.281) pointed out that, in addition to convincing the victim of the speaker's regret, apologies often serve such social functions as "to evince good manners, to assuage the recipient's wrath, or simply to get off the hook and be one's way."

\section{METHODOLOGY}

Twenty-two participants took part in this study: 11 males and 11 females students of second year studying in the same higher education institution. They were selected based on speaking Setswana very well. Quantitative research methodology served for collecting and analysing data for the purpose of the study. The model used for data classification was of Brown and Levinson (1978). The data in this study was collected through a Discourse completion tasks of questionnaire, encompassed a concise description of the situations based on suggested role plays of written or spoken by participants (Blumka-Kulka \& Olshtain, 1984; Cohen \& Olshtain, 1981; Olshtain, 1983; Trosborg, 1987). In other words, the questionnaire entailed of 5 fixed discourse situations, which the student is expected to encounter in his/her daily language interactions. The students reading each situation were then supposed to identify themselves with the persons committing the offenses in the apology situations and write down their normal language reaction in such situations. An analysis of the strategies will be done to see the situation with the most apology strategies. Total number of strategies in each situation and the total number of strategies between males and females will be determined. 


\subsection{Apology Situations}

\subsubsection{Talk: Making Noise While Other Students are Studying}

The situation which will be involved is Talk because it appears to account for all instances in higher learning institution situations. In talking situation, the offense involves some king of intrusion on the recipient's or talking turn or another infringement of rules for polite talk. The sub situations for talking include noise, insult, and phone.

Baithuti ba mo laeboraring. Ke nako ya motshegare ya go bala. Moithuti mongwe le mongwe o lebane le dibuka tsa gagwe. Go setlhopha sa ba ba tsayang kgang ka buka ya Setswana e ba e sekasekang. Se, se baka modumo o o feretlhang baithuti ba bangwe.

Students are in the library. It is in the afternoon where every student is busy studying. There is a group of students who are analysing a Setswana text with a high volume of noise, that disturb other students.

Complaint:

Mongwe wa baithuti o ile go motsamaisi wa laeborari go ngongorega ka modumo o o dirwang ke setlhopha se, sa baithuti.

One of the students went to the librarian to complain about the noise caused by the group of students.

Apology:

Setlhopha sa baithuti se ile sa kopa maitshwarelo go baithuti ba bangwe.

A group of students then apologized to other students.

2.1.2 Insult

Offend/insult someone in a meeting

Situation:

Mo kopanong, baithuti ga ba utlwane le se modulasetilo wa moemedi wa mokgatlho wa baithuti a se dirang. $O$ reetsa yo, a bue le yo, a sa bue pele le go fetsa pele le motho a le mongwe go mo utlwalela le go fetsa ka puo ya gagwe. Kwa bofelong ga a rarabolola sepe. Se, se kgopisa mongwe wa ba tla pitsong, e bile o mmolelela gore e kete o tholwa ke maemo, a role marapo, a fe motho yo a mo tshwanetseng.

In a meeting, the students are not in favour of the way the Chairperson of the Student Representative council $(S R C)$ is addressing issues. There is no individual attention, he listens to every student at the same time. One of the students who came to the meeting told him that he is not capable enough to hold a meeting, he must step down and give somebody who is capable.

Complaint:

Mongwe wa baithuti o ile a ngongorega ba ntse ba le mo pitsong.

One of the students complained while in the meeting.

Apology:

O ile a ikopela maitshwarelo mo baithuting ba bangwe.

He then apologizes to the other students.

\subsubsection{Phone}

Speak too long on a cell phone.

\section{Situation:}

Moithuti o araba mogala wa letheka mo phaphosing ya kamuso. O buela kwa godimo mme e bile o iketlile ga a tlotle le motlhatlheledi. Baithuti ba bangwe ba a ngongorega, ba leka go mo kgalema mme o tswelela pele fela.

One of the students is answering the cell phone in the lecture room. She talks very loud and very relaxed; she does not respect the lecturer. Some students are complaining and try to reproach him but continuing talking. 


\section{Complaint:}

Morago ga gore a fetse go bua, ke fa baithuti ba ngongorega ka mokgwa wa gagwe.

After he has finished to talk, students complained about his behaviour.

Apology:

O ile a ikopela maitshwarelo.

He then apologises to the students.

\subsubsection{Group Discussion}

Not taking part in group discussion

\section{Situation:}

Baithuti ba kgaogantswe ka ditlhopha. Ba filwe setlhogo se ba tshwanetseng go se sekaseka. Botlhe ba tsaya karolo kwa ntle ga moithuti a le mongwe, yo o didimetseng fela, mo setlhopheng seo.

Students are divided into groups. They are given a topic to discuss it as a group. They are all participating with the exception of one student who is quiet in the group.

Complaint:

Moeteledi wa setlhopha o bitsa motlhatlheledi a ngongorega ka moithuti yo.

The group leader calls the lecturer to complain about this student.

Apology:

Moithuti o kopa maitshwarelo go setlhopha sa baithuti.

The student apologizes to the group of students.

\section{ANALYSIS AND DISCUSSION OF RESULTS}

\subsection{Completion of the Questionnaire}

22 B.Ed. second year Setswana students of higher learning institution in the Free State Province, completed the questionnaire. Males completed the part of the offence or complaint for 4 questionnaires while females did the same with the other. After that, males took questionnaires completed by females to complete the apology part and females also completed the apology part of those which were first done i.e. the offence or the complaint part by males.

\subsection{Analysis of the Apologies}

Table 1: Apology situations and apology strategies

\begin{tabular}{|lc|c|c|c|c|c|}
\cline { 2 - 7 } \multicolumn{1}{c|}{} & Number & $\%$ & Number & $\%$ & Number & $\%$ \\
\hline 1.TALKING & 103 & 23.1 & 51 & 22.7 & 52 & 23.5 \\
\hline 1.1 Noise & 26 & 26 & 13 & 25.5 & 13 & 25 \\
\hline 1.2 Insult & 24 & 24 & 11 & 21.6 & 13 & 25 \\
\hline 1.3 Phone & 27 & 27 & 15 & 29.4 & 12 & 23 \\
\hline 1.4 Discussion & 26 & 26 & 12 & 23.5 & 14 & 26.9 \\
\hline \multicolumn{1}{|c|}{ Total } & $\mathrm{A}: 103$ & & $\mathrm{~B}: 51$ & & $\mathrm{C}: 52$ & \\
\hline
\end{tabular}

The data in table 1 shows various apology strategies listed in a vertical order from situation 1 . The situation refers to those that have been listed in the questionnaire above. The numbers which appear next to these situations in a horizontal order reflect the total number of apology strategies which have been used in the 
situation 1 (Talking) a total number of 103 strategies have been used, i.e. $23.1 \%$ of the total number of strategies. Of these 103 strategies 51 (22.7) have been used by males and 52 (23.5) by females.

\subsection{The Major Situation}

Table 2: Major situation analysis

\begin{tabular}{|l|c|c|c|c|}
\hline & Situation & Total & Male & Female \\
\hline 1. & Talking & 23.1 & 22.7 & 23.5 \\
\hline
\end{tabular}

The table above, displays apology strategies which have been used in the situation, is classified as follows:

\subsubsection{Total Number of Strategies between Males and females}

Most strategies are used by Males with the longest apology in situation-Talking.

The situation relating to Talking, apology strategies are used more by participants to make sure that, even though they accept the offence, their offence was not planned and that they really apologize for that. They want their apology to be accepted to maintain a good relationship

\subsection{Strategies between Males and Females in the Major Situation}

\subsubsection{Talking}

Situation $1: 22.7-23.5=0.8 \%$

There is a significant difference in the number of strategies which have been used by males and females in situation 1 - Talking.

\subsection{Sub-Situations}

\subsubsection{Talking}

Table 3: Sub-situation comparison and analysis

\begin{tabular}{|l|c|c|c|c|}
\hline & Sub-situation & Total & Males & Female \\
\hline 1.1 & Noise & 26 & 25.5 & 25 \\
\hline 1.2 & Insult & 24 & 21.6 & 25 \\
\hline 1.3 & Phone & 27 & 29.4 & 23 \\
\hline
\end{tabular}

\subsection{Total Numbers of Strategies in Sub-Situations}

\section{Group 1: 1.3, 1.1, $1.2(27,26,24)$}

All the above sub situations have high number of strategies used. It means the offenses in the above situations were not committed intentionally because apologizers are taking their time to explain their positions.

\subsubsection{Total number of strategies between males and females}

\section{Males}

Group 1: $1.3(29.4,25.5)$

Group 2: $1.2(21.6)$

\section{Females}

Group 1: 1.1, $1.2(25,25)$

Group 2: $1.3(23)$

Both males and females, more strategies have been used in sub situations 1.2 and 1.3. In group 2 sub 
situation 1.2 has less numbers of strategies used by both males and females.

\subsection{Strategies between Males and Females in Sub-Situations}

Sub-situation 1.1: $25.5,25 .=0,5$

Sub-situation 1.2: $21.6,25=3.4$

Sub-situation 1.3: $29.4,23=6.4$

Sub-situation 1.3 has no significant difference because they are all taking it as their responsibility to clear the situation on how an offence has occurred.

The difference in sub-situation 1.1, the difference is significant because males are trying to be cooperative by apologizing with an explicit explanation so that females can accept their apology. Females do not want to elaborate too much because they think as softer sex, their situation will be justified.

\section{CONCLUSION}

It is evident that the situation of talking involves a lot of number of strategies than other situations. Students know that it is good to apologize for the usage of things that belong to others. Males do not want to involve many strategies to clear their offences as females do.

\section{REFERENCE LIST}

Austin, J. I. (1962). How to do things with words. Harvard and Oxford: University Press.

Blum-Kulka, S., House, J., \& Kasper, G. (1993). Cross-cultural pragmatics: Requests and apologies. Ablex.

Brown, P., \& Levinson S. C. (1987). Politeness: Some universals of language usage. Cambridge University Press.

Fraser, B. (1981). On Apologizing in New Zealand English. Language in Society.

Holmes, J. (1990). Apologies in New Zealand English. University of London.

Jaworski, A. (1994). Apologies and non-apologies: Negotiation in speech act realization. Walter de Gruyter.

Leech, G. N. (1983). Principles of Pragmatics. Longman.

Scher, S. J., \& Darley, J. M. (1997). How effective are the things people say to apologize? Effects of the realization of the apology speech act. Journal of Psycholinguistic Research, 26(1). https://doi.org/10.1023/A:1025068306386

Searl, J. R. (1969). Speech Act: An essay in the Philosophy of Language. Cambridge University Press.

Thomas, J. (1995). Meaning in Interaction: An introduction to Pragmatics. Longman.

Trosborg, A. (1995). Interlanguage Pragmatics: Requests, complaints, and apologies. Mouton de Gruyter.

Yule, G. (1996). Pragmatics. Oxford University. 